\title{
PENGEMBANGAN DESAIN PEMBELAJARAN MATEMATIKA KELAS V SD BERBASIS ETNOMATEMATIKA
}

\author{
Rismawati $^{1}$, Huri Suhendri ${ }^{2}$, Ihwan Zulkarnain ${ }^{3}$ \\ ${ }^{1,2,3}$ Universitas Indraprasta PGRI \\ yusupsopyan3@gmail.com ${ }^{1}$, huri-suhendri@unindra.ac.id ${ }^{2}$, \\ irvan_arie@yahoo.com ${ }^{3}$
}

\begin{abstract}
ABSTRAK
Tujuan dari penelitian ini adalah untuk mengembangkan desain pembelajaran matematika kelas V SD berbasis etnomatematika. Penelitian dilakukan pada SD dan MI di wilayah Kecamatan Pondok Gede, Kota Bekasi, Jawa Barat. Metode penelitian yang digunakan adalah metode penelitian dan pengembangan (Research and Develompment atau $R \& D$ ). Model pengembangan yang digunakan adalah model ADDIE (Analysis, Design, Development, Implementation, Evaluation). Tahapan dalam penelitian ini terdiri dari: pertama tahap analysis yaitu menentukan potensi, masalah, dan solusi yang tepat serta menentukan kompetensi peserta didik melalui analisis kebutuhan; kedua tahap design yaitu merumuskan tujuan pembelajaran, strategi pembelajaran, tingkah interaksi, dan prosedur evaluasi; ketiga tahap development yaitu melakukan pembuatan media pembelajaran berdasarkan indikator etnomatematika; keempat tahap implementation yaitu dengan menerapkan desain pembelajaran yang dikembangkan pada kondisi yang sebenarnya; dan kelima tahap evaluation yaitu melakukan penilaian produk oleh pakar atau ahli (pengembangan, media, dan materi) dan pengguna (guru dan peserta didik). Hasil dari penelitian ini adalah desain pembelajaran matematika berupa modul pembelajaran matematika berbasis etnomatematika bagi peserta didik kelas V SD/MI. Berdasarkan hasil penelitian dan simpulan, maka saran atau rekomendasinya adalah guru dapat menggunakan modul pembelajaran matematika berbasis etnomatematika dalam kegiatan pembelajaran di kelas.
\end{abstract}

Kata kunci: desain pembelajaran matematika, etnomatematika, pengembangan model ADDIE.

\begin{abstract}
The purpose of this study was to develop a mathematics learning design for fifth grade elementary school based on ethnomatatics. The study was conducted at SD and MI in the Pondok Gede sub-district, Bekasi, West Java. The research method used is the research and development method (Research and Development or R\&D). The development model used is the ADDIE model (Analysis, Design, Development, Implementation, Evaluation). The stages in this study consisted of: the first stage of analysis was determining potential, problems, and appropriate solutions and determining student competencies through needs analysis; the second stage of the design is formulating learning objectives, learning strategies, behavioral interactions, and evaluation procedures; the third stage of development is making learning media based on ethnomatematics indicators; the fourth stage of implementation is to apply the learning design that is developed in actual conditions; and the fifth stage of evaluation that is conducting product assessments by experts or experts (development, media, and material) and users (teachers and students). The results of this study are mathematics learning design in the form of ethnomatematics-based mathematics learning modules for fifth grade students of SD/MI. Based on the results of research and conclusions, the suggestion or recommendation is that teachers can use ethnomatematicsbased mathematics learning modules in classroom learning activities.
\end{abstract}

Keywords: design learning mathematics, ethnomatematics, development of the ADDIE model. 


\section{Rismawati, Huri Suhendri, Ihwan Zulkarnain}

\section{PENDAHULUAN}

Pendidikan merupakan faktor yang sangat penting untuk menyiapkan sumber daya manusia bagi pembangunan bangsa dan negara. Pendidikan bertujuan untuk memberikan bekal pengetahuan peserta didik supaya siap untuk menghadapi kehidupan nyata serta dapat membentuk menjadi manusia seutuhnya. Salah satu bidang ilmu yang mendukung untuk menjadi bekal pengetahuan adalah matematika. Hal ini sesuai pendapat Suhendri dan Ningsih (2018) bahwa "konsepkonsep matematika dalam diaplikasikan dalam berbagai bidang ilmu dan kehidupan nyata manusia". Tujuan pembelajaran matematika dapat membentuk logika berpikir, bukan sekedar pandai berhitung saja. Berhitung dapat dilakukan dengan alat bantu, seperti kalkulator dan komputer, namun menyelesaikan masalah perlu logika berpikir dan analisis.

Namun, sebagian peserta didik menganggap matematika merupakan pelajaran yang sulit dipahami. Sehingga, peserta didik tidak menyukai pelajaran matematika, dikarenakan pembelajaran matematika yang rumit dan membosankan saat dipelajari maupun dipahami materi dan soal yang terdapat pada pembelajaran di sekolah. Suhendri (2013) menyatakan bahwa "salah satu masalah yang perlu disoroti adalah anggapan sebagian besar peserta didik yang menyatakan bahwa matemaika merupakan satu mata pelajaran yang sukar, sulit bahkan menakutkan, ditambah lagi dengan penampilan guru matematika yang terkesan tidak bersahabat dengan peserta peserta didik".

Masalah pembelajaran matematika pada saat ini adalah kurangnya minat peserta didik untuk mempelajari matematika dikarenakan sulitnya memahami soal matematika dan rasa malas yang timbul saat mempelajari matematika. Faktor tersebut menyebabkan nilai matematika peserta didik mengalami penurunan. Hal ini dilihat dalam kondisi pembelajaran di tempat penelitian yang hasilnya menunjukkan bahwa kurangnya minat anak dalam belajar matematika serta minat dalam melatih diri dengan mengerjakan soal-soal pada saat di rumah dan kurangnya perhatian anak dalam mengerjakan soal matematika. Rendahnya hasil belajar matematika dapat dilihat dari tingkat ketuntasan belajar peserta didik di sekolah. Berikut rata-rata tingkat ketuntasan hasil belajar matematika peserta didik SD/MI berdasarkan hasil observasi dibeberapa sekolah wilayah Bekasi dapat 

dilihat pada Tabel 1.

Tabel 1. Rata-Rata Tingkat Ketuntasan Hasil Belajar Matematika SD/MI

\begin{tabular}{lc}
\hline \multicolumn{1}{c}{ Nama Sekolah } & Rata-Rata yang Tuntas \\
\hline SDN Jatibening Baru IV & $67 \%$ \\
MI Miftahul Amal & $42 \%$ \\
SDIT Ar-Raudhah & $65 \%$ \\
\hline
\end{tabular}

Sumber: Dokumen nilai matematika guru matematika tahun 2018-2019

Berdasarkan Tabel 1, rata-rata tingkat ketuntasan hasil belajar matematika peserta didik SD/MI di wilayah tersebut masih rendah. Hal tersebut tidak berbeda jauh dari penelitian Sumianto (2018) yang menunjukkan bahwa hasil observasi nilai pembelajaran matematika SD masih rendah dan dapat dilihat dari salah satu hasil persentase KKM peserta didik yang mendapat rata-rata nilai yaitu 62,50\%.

Pembelajaran matematika juga diajarkan untuk membantu melatih pola pikir peserta didik agar dapat menyelesaikan masalah dengan cermat. Selain itu, pembelajaran matematika diajarkan agar kepribadian peserta didik terbentuk serta terampil menggunakan matematika sehari-hari. Pada dasarnya pembelajaran matematika juga tidak terlepas dari budaya lokal di sekitarnya, karena di dalam suatu budaya tak jarang memuat konsep-konsep matematika yang diterapkan dalam kehidupan sehari-hari secara turun-temurun. Pembelajaran matematika berdasarkan atau mengkaitkan dengan budaya disebut dengan etnomatematika.

Etnomatematika merupakan suatu pengetahuan yang mengaitkan matematika dengan unsur budaya. Menurut Nusantara dan Rahardjo (2017), "etnomatematika adalah praktik matematika dalam kelompok budaya". Artinya etnomatematika merupakan penerapan konsep-konsep matematika dalam budaya atau kebiasaan di suatu kelompok masyakarat. Hal ini sesuai dengan pendapat Vasquez (2017) bahwa "etnomatematika tidak hanya membahas pengetahuan matematika tetapi juga bahasa, nilai, perilaku, pengetahuan, dan praktik yang kelompok budaya menyebar di lingkungan tertentu". Wujud keterkaitannya dapat diperlihatkan dalam aspek penerapan konsep-konsep matematika dalam suatu budaya, serta cara mengerjakan matematika yang sesuai dengan budaya lokal. 


\section{Rismawati, Huri Suhendri, Ihwan Zulkarnain}

Konsep matematika dalam suatu budaya akan peneliti kembangkan dalam desain pembelajaran khususnya modul pembelajaran untuk peserta didik kelas $\mathrm{V}$ SD. Hal ini diperkuat dengan hasil penelitian Dahlan dan Permatasari (2018) menunjukan bahwa bahan ajar berbasis etnomatematika mampu memfasilitasi peserta didik dalam mengkontruksi pengetahuan matematika secara induktif. Modul pembelajaran merupakan bagian dari desain pembelajaran yang biasa digunakan oleh guru maupun peserta didik saat proses belajar mengajar di kelas. Modul berisi materi pembelajaran yang bervariatif supaya dapat membuat peserta didik semangat saat mempelajarinya.

Tetapi, dari hasil analisis kebutuhan menunjukkan bahwa ada beberapa bahan ajar modul matematika isinya kurang variatif dan kurangnya latihan-latihan soal. Hal ini dikemukakan oleh Wijanarko (2017) bahwa materi pada media pembelajaran masih bersifat abstrak dan kurang variatif menjadi masalah pemahaman peserta didik. Oleh karena itu peneliti ingin mengembangkan modul sebagai salah satu media pembelajaran matematika yang variatif agar dapat menumbuhkan rasa keingin tahuan pada peserta didik terhadap matematika serta menumbuhkan semangat dan tidak mudah bosan ketika mempelajari matematika dengan menerapkan unsur budaya agar dapat mempermudah peserta didik dalam mengetahui keberagaman budaya yang ada di Indonesia. Oleh karena itu, guru membutuhkan bahan ajar modul yang menarik dan mudah dipahami untuk menunjang pembelajaran yang lebih efektif. Hal tersebut dijelaskan oleh Zuriah, dkk (2016) bahwa pembelajaran yang menarik, efektif, dan efisien tentunya membutuhkan bahan ajar yang inovatif.

Berdasarkan uraian di atas, peneliti tertarik untuk melakukan penelitian dengan judul "Pengembangan Desain Pembelajaran Matematika Sekolah Dasar Kelas V SD Berbasis Etnomatematika”. Desain pembelajaran dari penelitian ini diharapkan dapat membantu meningkatkan pemahaman dan semangat peserta didik dalam proses pembelajaran serta dapat mengetahui keberagaman budaya disekitarnya. 


\section{METODE PENELITIAN}

Penelitian dilaksanakan di SD/MI di wilayah Kecamatan Jati Asih dan Pondok Gedo, Kota Bekasi, Jawa Barat selama 6 bulan dari bulan Maret s.d. Agustus 2019. Peneliti mengambil 3 SD/MI sebagai tempat penelitian, yaitu SDN Jatibening Baru IV, SDIT Ar-Raudhah, dan MI Miftahul Amal. Responden dalam penelitian ini adalah guru matematika atau guru kelas $\mathrm{V}$ dan peserta didik kelas $\mathrm{V}$ dari masing-masing sekolah yang menjadi tempat penelitian.

Jenis penelitian yang digunakan dalam penelitian ini yaitu penelitian kualitatif dengan metode penelitian dan pengembangan (resarch and development). Sugiyono (2015) menjelaskan bahwa penelitian dan pengembangan adalah penelitian yang digunakan untuk menghasilkan produk tertentu dan menguji keefektifan produk tersebut. Produk yang dikembangkan adalah desain pembelajaran pada mata pelajaran matematika Sekolah Dasar kelas V sebagai sumber belajar matematika peserta didik. Penelitian dan pengembangan dilakukan bertujuan untuk mengembangkan suatu produk dengan memodifikasi produk yang telah ada agar pembelajaran dapat berjalan lebih baik dan efektif. Pengembangan desain pembelajaran dalam penelitian ini mengacu pada Model ADDIE oleh (Trisiana \& Wartoyo, 2016) terdiri dari lima tahap seperti Gambar 1.

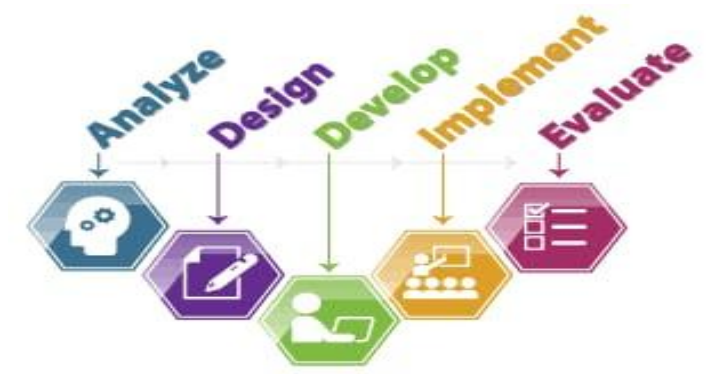

\section{Gambar 1. Tahap-Tahap Model ADDIE}

Lima tahapan pengembangan penelitian sebagai berikut:

1. Analysis (Analisa)

Tahap analisis untuk mengetahui dengan jelas bagaimana keadaan lapangan sebenarnya. Menurut Afandi (2013), tahap analisis merupakan suatu proses mendefinisikan apa yang dipelajari oleh peserta belajar, yaitu menganalisa kebutuhan, mengidentifikasi masalah, dan melakukan analisis tugas.

Tahap analisis ini bertujuan untuk menentukan potensi, masalah, dan 


\section{Rismawati, Huri Suhendri, Ihwan Zulkarnain}

solusi yang tepat serta menentukan kompetensi peserta didik. Secara garis besar, beberapa hal yang akan peneliti analisis, yaitu:

a. Analisis karakter peserta didik V SD/MI, meliputi respon peserta didik terhadap pembelajaran matematika dan hasil belajar matematika secara umum.

b. Analisis materi yang terdapat pada modul matematika yang akan digunakan, meliputi kurikulum, standar kompetensi, dan indikator yang harus dicapai peserta didik setelah belajar matematika.

c. Analisis SDM, dalam hal ini adalah pemahaman guru dan peserta didik dalam pembelajaran matematika berbasis etnomatematika.

2. Design (Desain)

Tahap desain dilaksanakan untuk mencapai dua aspek tujuan, yaitu pembelajaran dan fungsional. Kegiatan desain untuk mencapai aspek pembelajaran diistilahkan sebagai desain fungsional. Desain pembelajaran dilakukan untuk merumuskan tujuan pembelajaran, strategi pembelajaran, tingkah interaksi, dan prosedur evaluasi.

Pada tahap desain, difokuskan pada upaya untuk menyelidiki masalah dan menemukan alternatif solusi yang akan dilakukan untuk dapat mengatasi masalah pembelajaran yang diidentifikasi dalam tahap analisis kebutuhan. Pada tahap ini diperlukan adanya klarifikasi rancangan media pembelajaran sehingga pembelajaran tersebut dapat mencapai tujuan seperti yang diharapkan. Langkahlangkah yang dilakukan pada tahap ini yaitu:

a. Menentukan tujuan pembelajaran matematika kelas V SD/MI.

b. Menentukan materi yang sesuai dengan silabus matematika kelas V SD/MI.

c. Menyusun desain modul pembelajaran matematika kelas V SD/MI yang akan dikembangkan.

d. Menentukan strategi pembelajaran yang akan digunakan dalam pembelajaran matematika menggunakan modul matematika kelas $\mathrm{V}$ SD/MI yang dikembangkan.

3. Development (Pengembangan)

Dalam tahap pengembangan, kegiatan yang dilakukan yaitu:

a. Pembuatan modul pembelajaran matematika berbasis etmomatematika untuk kelas V SD/MI. 
b. Pembuatan instrumen penilaian bagi pakar.

c. Melakukan penilaian oleh pakar, yang terdiri dari pakar pengembangan, materi, dan bahasa dengan jumlah masing-masing 1 orang pakar.

\section{Implementation (Implementasi)}

Pada tahap implementasi, modul pembelajaran yang dikembangkan dan sudah dinilai oleh pakar serta direvisi kemudian diimplementasikan pada kegiatan pembelajaran di kelas pada kondisi yang sebenarnya. Pengambilan peserta didik untuk ujicoba produk diambil untuk kelas V SD/MI.

\section{Evaluation (Evaluasi/Umpan Balik)}

Pada tahap ini adalah menganalisa sejauh mana kelayakan media yang telah dikembangkan berdasarkan langkah-langkah berikut:

a. Mengevaluasi produk berdasarkan penilaian dan masukan dari para ahli.

b. Mengevaluasi produk berdasarkan masukan dari guru dan peserta didik.

Teknik pengumpulan data dalam penelitian ini adalah 1) Observasi, bertujuan untuk mengumpulkan data dengan jalan mengadakan pengamatan terhadap kegiatan yang sedang berlangsung. Dengan observasi, peneliti akan mengetahui keadaan di sekolah untuk menganalisis kebutuhan yang akan dijadikan bahwa awal untuk pengembangan media pembelajaran. 2) Kuesioner, bertujuan untuk memperoleh atau mengumpulkan data dengan memberikan daftar pernyataan secara tertulis kepada responden/ subjek penelitian. 3) Wawancara, bertujuan untuk mengetahui secara langsung pendapat dari responden dengan cara melakukan tanya jawab yang sistematis dan hasil tanya jawab dicatat secara cermat.

Instrumen yang digunakan dalam penelitian ini adalah: 1) Pedoman wawancara, berisi berupa kumpulan pertanyaan yang akan dinyatakan pada guru dan peserta didik. 2) Lembar Penilaian untuk Ahli, penelitian ini menggunakan lembar penilaian dengan 4 (empat) alternatif jawaban. Alternatif jawaban yang diberikan berupa skor penilaian diberikan dengan menggunakan skala Likert. Untuk pertanyaan dengan skor yang tertinggi, 1 = sangat kurang, $2=$ kurang, $3=$ baik/ jelas/ sesuai, dan 4 = sangat baik/ sangat jelas/ sangat sesuai. 3) Kuisioner, berupa berupa pernyataan yang diberikan kepada guru dan peserta didik terhadap produk yang telah dikembangkan. 


\section{Rismawati, Huri Suhendri, Ihwan Zulkarnain}

Teknik analisis data menggunakan teknik analisis deskriptif kualitiatif yang memaparkan hasil pengembangan desain pembelajaran matematika berbasis etnomatematika. Instrumen yang digunakan berupa range presentase seperti pada tabel berikut.

Tabel 2. Interval dan Kriteria Penilaian oleh Pakar

\begin{tabular}{ccc}
\hline No. & Interval & Kriteria \\
\hline 1. & $76 \%<$ skor $<100 \%$ & Sangat Baik \\
2. & $51 \%<$ skor $<75 \%$ & Baik \\
3. & $26 \%<$ skor $<50 \%$ & Kurang Baik \\
4. & $0 \%<$ skor, $25 \%$ & Tidak Baik \\
\hline
\end{tabular}

\section{HASIL PENELITIAN DAN PEMBAHASAN}

Hasil penelitian pengembangan ini adalah tersusunnya media pembelajaran matematika bernuansa etnomatematika sekaligus memperkenalkan kebudayaan di Indonesia untuk memfasilitasi peserta didik dalam pencapaian tujuan pembelajaran serta dapat meningkatkan minat belajar matematika. Suparman (2012) menyatakan bahwa kebutuhan merupakan suatu kesenjangan yang terjadi saat ini dibandingkan dengan keadaan yang diinginkan. Peserta didik kelas V SD merupakan peserta didik yang sudah dituntut untuk memahami serta menguasai kompetensi-kompetensi dasar matematika untuk bekal mereka dijenjang pendidikan selanjutnya yang lebih sulit.

Proses yang dilakukan sebelum menyusun bahan media pembelajaranyakni tahap Analysis (Analisis), Design (Desain), Development (Pengembangan), Implementation (Penerapan), dan Evaluation (Evaluasi) yang dimodifikasi oleh peneliti. Kelima tahapan model ADDIE dalam pengembangan media belajar ini dilakukan secara sistematis. Berikut pembahasan tahap-tahap dalam pengembangan media belajar dalam pembelajaran matematika yang sesuai dengan model ADDIE.

\section{Penelitian pendahuluan}

Sebelum pengembangan modul berbasis etnomatematika untuk tingkat Sekolah Dasar kelas V ini dilakukan, peneliti melakukan penelitian pendahuluan melalui kuesioner, observasi, dan wawancara pada peserta didik dan guru 
matematika di SDN Jatibening Baru IV, MI Mifathul Amal, dan SDIT ArRaudhah. Penelitian dilakukan ditiga sekolah wilayah Bekasi yang bertujuan untuk mendapatkan hasil yang relevan dan objektif sesuai dengan kebutuhan dari penelitian ini sebagai dasar masalah penelitian. Guru yang diwawancarai sebanyak 4 orang dan peserta didik yang diwawancarai sebanyak 6 orang.

\section{a. Hasil observasi}

Berdasarkan hasil observasi peneliti terhadap proses pembelajaran yang dilakukan di kelas V SDN Jatibening Baru IV, MI Miftahul Amal, dan SDIT ArRaudhah untuk pembelajaran matematika. Observasi dilakukan pada bulan Maret 2019 di ketiga sekolah. Jumlah peserta didik yang mengikuti pembelajaran pada observasi awal sebanyak 115 peserta didik. Proses pembelajaran diawali dengan mengucapkan salam, berdoa, dan pembelajaran inti.

Ketika proses pembelajaran berlangsung, guru mengulas sedikit pembelajaran yang diajarkan dipertemuan sebelumnya. Setelah mengulas pembelajaran, guru menjelaskan pembelajaran yang akan dipelajari pada pertemuan saat itu. Proses pembelajaran matematika dalam seminggu berjumlah 6 jam pelajaran yang disampaikan oleh guru dengan metode konvensional. Media pembelajaran modul jarang sekali digunakan saat berlangsungnya pembelajaran. Penyampaian materi biasa menggunakan modul lain selain yang digunakan oleh sekolah dengan cara didikte atau melalui media papan tulis. Saat guru memberi latihan pun biasanya tidak menggunakan modul melainkan dengan menulis di papan tulis. Hal ini membuat peserta didik kurang berkembang saat berlatih latihan soal sekolah di rumah.

\section{b. Hasil wawancara}

Berdasarkan hasil wawancara dengan guru matematika diketiga sekolah, guru-guru tersebut memiliki jawaban yang hampir sama mengenai karakter peserta didik disetiap sekolah. Karakter yang dimaksud adalah ada peserta didik yang dapat mengikuti pelajaran dengan baik dan ada yang tidak bisa mengikuti pelajaran, lebih berminat pada hal-hal yang konkret, dan terdapat perbedaan yang mencolok pada minat pelajaran tertentu. Ketiga sekolah juga memiliki jawaban serupa mengenai karakter peserta didik setelah menerima pelajaran matematika yaitu ada yang menyukai matematika dan adapula yang menganggap bahwa 


\section{Rismawati, Huri Suhendri, Ihwan Zulkarnain}

matematika merupakan pelajaran yang sulit dipahami. Hasil kuesioner mengenai media yang digunakan oleh guru matematika di ketiga sekolah pun serupa yaitu dengan membuat atau menggunakan media atau alat peraga sendiri untuk menarik perhatian peserta didik agar lebih memudahkan peserta didik dalam memahami konsep pembelajaran, dikarenakan materi yang ada pada modul agak sulit dipahami dan juga memiliki beberapa kekurangan yang hampir serupa yaitu kurangnya variatif tugas latihan dan kurangnya latihan soal HOTS yang dapat melatih peserta didik berpikir tingkat tinggi. Mengenai budaya, guru di tiga sekolah memiliki jawaban bahwa sebagian besar peserta didik kurang mengenal dan memahami budaya di sekitar termasuk budaya teman sekelasnya.

Penelitian pendahuluandi tiga sekolah tersebut hampir memiliki alasan yang sama untuk mengembangkan media belajar modul berbasis etnomatematika ini untuk proses pembelajaran peserta didik. Modul ini dirasa dapat memudahkan peserta didik dalam belajar matematika. Disamping dapat membuat semangat peserta didik dalam belajar matematika dan juga dapat mengetahui keberagaman budaya yang berada disekitarnya.

\section{c. Hasil studi dokumentasi}

Tingkat ketuntasan hasil belajar matematika peserta didik SD/MI berdasarkan hasil observasi dibeberapa sekolah wilayah Bekasi adalah bahwa rata-rata tingkat ketuntasan hasil belajar matematika peserta didik SD/MI di wilayah tersebut masih rendah (berdasarkan hasil observasi yang ditampilkan pada pendahuluan. Studi dokumentasi juga dilakukan dalam melihat perangkat pembelajaran yang digunakan oleh guru terkait penggunaan media pembelajaran dalam RPP dan tujuan pembelajaran matematika.

\section{Analysis (Analisis)}

Analisis kebutuhan merupakan kegiatan pertama yang dilakukan oleh setiap perancang khususnya perancang pembelajaran. Analisis tersebut bertujuan mengetahui alasan apa yang melatarbelakangi sebuah desain pembelajaran yang dikembangkan. Pembelajaran yang akan didesain saat ini adalah pelajaran matematika yang diberikan kepada peserta didik kelas V Sekolah Dasar secara umum masih mempelajari tentang operasi hitung pecahan, perbandingan suatu besaran dan skala, bangun ruang dan jaring-jaring, dan penyajian data. Meskipun 
sederhana, peserta didik kelas $\mathrm{V}$ diharapkan mampu menguasai konsep-konsep materi yang disajikan.

Tabel 3. Hasil Analisis Kebutuhan melalui Wawancara dengan Guru Matematika

\begin{tabular}{|c|c|c|c|c|c|}
\hline $\begin{array}{c}\text { Karakteristik } \\
\text { Umum Peserta } \\
\text { Didik SD }\end{array}$ & $\begin{array}{c}\text { Sikap } \\
\text { Perilaku } \\
\text { Peserta Didik } \\
\text { Kelas V SD } \\
\text { saat } \\
\text { Menerima } \\
\text { Pelajaran } \\
\text { Matematika }\end{array}$ & $\begin{array}{c}\text { Kompetensi } \\
\text { yang Harus } \\
\text { Dimiliki oleh } \\
\text { Peserta } \\
\text { Didik Kelas } \\
\text { V SD }\end{array}$ & $\begin{array}{c}\text { Media } \\
\text { Pembelaja- } \\
\text { ran yang } \\
\text { digunakan }\end{array}$ & $\begin{array}{l}\text { Pengetahuan } \\
\text { Peserta didik } \\
\text { terhadap } \\
\text { Budaya } \\
\text { disekitarnya }\end{array}$ & Sumber \\
\hline $\begin{array}{l}\text { Lebih } \\
\text { berminat } \\
\text { pada hal-hal } \\
\text { konkret, } \\
\text { selalu ingin } \\
\text { tahu dan } \\
\text { belajar, dan } \\
\text { mendapat } \\
\text { perbedaan } \\
\text { yang } \\
\text { mencolok } \\
\text { pada minat } \\
\text { pelajaran } \\
\text { tertentu }\end{array}$ & $\begin{array}{l}\text { Sebagian kecil } \\
\text { antusias } \\
\text { sedangkan } \\
\text { yang lainnya } \\
\text { biasa saja }\end{array}$ & $\begin{array}{l}\text { Mengenal, } \\
\text { mengingat, } \\
\text { menerapkan, } \\
\text { menyimpul- } \\
\text { kan, } \\
\text { menjelaskan, } \\
\text { mencari } \\
\text { solusi, } \\
\text { mencari dan } \\
\text { memahami } \\
\text { hubungan }\end{array}$ & $\begin{array}{l}\text { Media yang } \\
\text { dapat } \\
\text { menjelaskan } \\
\text { hal-hal yang } \\
\text { konseptual } \\
\text { menjadi hal } \\
\text { yang } \\
\text { konkret }\end{array}$ & $\begin{array}{l}\text { Sebagian } \\
\text { besar } \\
\text { kurang } \\
\text { memahami } \\
\text { dan budaya } \\
\text { disekitar }\end{array}$ & $\begin{array}{l}\text { Guru } \\
\text { Kelas V } \\
\text { SDN } \\
\text { Jatibening } \\
\text { Baru IV }\end{array}$ \\
\hline $\begin{array}{l}\text { Tidak bisa } \\
\text { diam bila } \\
\text { diberi tugas, } \\
\text { dan lebih } \\
\text { cenderung } \\
\text { antusias } \\
\text { melakukan } \\
\text { sesuatu yang } \\
\text { menyenang- } \\
\text { kan }\end{array}$ & $\begin{array}{l}\text { Sebagian besar } \\
\text { peserta didik } \\
\text { fokus dalam } \\
\text { menerima } \\
\text { pelajaran } \\
\text { matematika, } \\
\text { namun ada } \\
\text { beberapa } \\
\text { peserta didik } \\
\text { yang masih } \\
\text { asik sendiri. }\end{array}$ & $\begin{array}{l}\text { Peserta didik } \\
\text { menguasai } \\
\text { perkalian }\end{array}$ & $\begin{array}{l}\text { Media } \\
\text { untuk } \\
\text { menghafal } \\
\text { perkalian, } \\
\text { karton } \\
\text { untuk } \\
\text { materi } \\
\text { bangun } \\
\text { ruang, dan } \\
\text { jam untuk } \\
\text { pembelaja- } \\
\text { ran waktu }\end{array}$ & $\begin{array}{l}\text { Peserta } \\
\text { didik mulai } \\
\text { megetahui } \\
\text { budaya } \\
\text { temannya } \\
\text { yang } \\
\text { berbeda } \\
\text { dengannya }\end{array}$ & $\begin{array}{l}\text { Guru } \\
\text { Kelas V } \\
\text { SDN } \\
\text { Jatibening } \\
\text { Baru IV }\end{array}$ \\
\hline $\begin{array}{l}\text { Rata-rata } \\
\text { peserta didik } \\
\text { tidak bisa } \\
\text { mengikuti } \\
\text { pelajaran }\end{array}$ & $\begin{array}{l}\text { Saat } \\
\text { diterangkan } \\
\text { peserta didik } \\
\text { memperhati- } \\
\text { kan dapat } \\
\text { mengerti } \\
\text { pelajaran, } \\
\text { tetapi ketika } \\
\text { diubah angka }\end{array}$ & $\begin{array}{l}\text { Peserta didik } \\
\text { harus bisa } \\
\text { perkalian } \\
\text { maupun } \\
\text { pembagian }\end{array}$ & $\begin{array}{l}\text { Alat peraga } \\
\text { rubik dan } \\
\text { kardus } \\
\text { untuk } \\
\text { materi } \\
\text { bangun } \\
\text { ruang }\end{array}$ & $\begin{array}{l}\text { Kurangnya } \\
\text { pengetahu- } \\
\text { an budaya }\end{array}$ & $\begin{array}{l}\text { Guru } \\
\text { Kelas V } \\
\text { MI } \\
\text { Miftahul } \\
\text { Amal }\end{array}$ \\
\hline
\end{tabular}


Rismawati, Huri Suhendri, Ihwan Zulkarnain

\begin{tabular}{|c|c|c|c|c|c|}
\hline $\begin{array}{c}\text { Karakteristik } \\
\text { Umum Peserta } \\
\text { Didik SD }\end{array}$ & $\begin{array}{c}\text { Sikap } \\
\text { Perilaku } \\
\text { Peserta Didik } \\
\text { Kelas V SD } \\
\text { saat } \\
\text { Menerima } \\
\text { Pelajaran } \\
\text { Matematika }\end{array}$ & $\begin{array}{c}\text { Kompetensi } \\
\text { yang Harus } \\
\text { Dimiliki oleh } \\
\text { Peserta } \\
\text { Didik Kelas } \\
\text { V SD }\end{array}$ & $\begin{array}{c}\text { Media } \\
\text { Pembelaja- } \\
\text { ran yang } \\
\text { digunakan }\end{array}$ & $\begin{array}{c}\text { Pengetahuan } \\
\text { Peserta didik } \\
\text { terhadap } \\
\text { Budaya } \\
\text { disekitarnya }\end{array}$ & Sumber \\
\hline & $\begin{array}{l}\text { saat latihan } \\
\text { peserta didik } \\
\text { menjadi } \\
\text { bingung }\end{array}$ & & & & \\
\hline $\begin{array}{l}\text { Peserta didik } \\
\text { mampu } \\
\text { menyelesai- } \\
\text { kan masalah } \\
\text { dalam situasi } \\
\text { konkret dan } \\
\text { peserta didik } \\
\text { aktif dan } \\
\text { merasa lebih } \\
\text { tahu. }\end{array}$ & $\begin{array}{l}\text { Sebagian besar } \\
\text { peserta didik } \\
\text { antusias tetapi } \\
\text { sebagian kecil } \\
\text { lainnya } \\
\text { khawatir tidak } \\
\text { bisa mengikuti } \\
\text { matematika }\end{array}$ & $\begin{array}{l}\text { Kemampuan } \\
\text { berfikir logis, } \\
\text { analitis, } \\
\text { sistematis, } \\
\text { kritis, } \\
\text { inovatif dan } \\
\text { kreatif, serta } \\
\text { bekerjasama. }\end{array}$ & $\begin{array}{l}\text { Alat peraga } \\
\text { yang } \\
\text { menarik }\end{array}$ & $\begin{array}{l}\text { Sebagian } \\
\text { besar } \\
\text { peserta } \\
\text { didik hanya } \\
\text { mengetahui } \\
\text { budayanya } \\
\text { masing- } \\
\text { masing }\end{array}$ & $\begin{array}{l}\text { Guru } \\
\text { Kelas V } \\
\text { SDIT Ar- } \\
\text { Raudhah }\end{array}$ \\
\hline
\end{tabular}

Dari hasil wawancara pada Tabel 3, dapat diambil keputusan sebagai berikut:

a. Karakteristik Siswa SD

Secara keseluruhan karakteristik siswa kelas V SD memiliki karakteristik yang beragam. Siswa cenderung menyukai hal yang lebih konkret dan lebih bersemangat jika melakukan sesuatu yang menyenangkan (belajar sambil bermain). Oleh karena itu, pendidik diharapkan mampu memberikan sebuah desain pembelajaran matematika yang dapat memotivasi siswa dalam belajar matematika.

b. Kendala dalam Proses Pembelajaran

Kendala yang dialami selama proses pembelajaran di SDN Jatibening Baru IV, MI Miftahul Amal, dan SDIT Ar-Raudhah adalah kurangnya fokus siswa ketika guru sedang menjelaskan pembelajaran. Hal ini menandakan kurangnya desain pembelajaran yang sesuai dan menarik dengan kebutuhan siswa. 
Pengembangan Desain Pembelajaran Matematika Kelas V SD Berbasis Etnomatematika

Tabel 4. Hasil Analisis Kebutuhan Melalui Wawancara dengan Peserta Didik Kelas V

\begin{tabular}{|c|c|c|c|c|}
\hline $\begin{array}{c}\text { Respon } \\
\text { Peserta didik } \\
\text { terhadap } \\
\text { Pelajaran } \\
\text { Matematika }\end{array}$ & $\begin{array}{c}\text { Pembelajaran } \\
\text { Matematika } \\
\text { di Kelas }\end{array}$ & $\begin{array}{c}\text { Respon } \\
\text { mengenai } \\
\text { Modul } \\
\text { Matematika } \\
\text { di Sekolah }\end{array}$ & $\begin{array}{c}\text { Respon } \\
\text { Pengetahuan } \\
\text { Peserta didik } \\
\text { terhadap } \\
\text { Budaya } \\
\text { Teman } \\
\text { Sekelas }\end{array}$ & Sumber \\
\hline Agak Sulit & Berdiskusi & $\begin{array}{l}\text { Agak Sulit } \\
\text { dipahami }\end{array}$ & $\begin{array}{l}\text { Iya, Jawa, } \\
\text { Sunda, Betawi, } \\
\text { Padang }\end{array}$ & $\begin{array}{l}\text { Peserta didik } \\
\text { SDN } \\
\text { Jatibening } \\
\text { Baru IV }\end{array}$ \\
\hline Seru & Berdiskusi & $\begin{array}{l}\text { Mudah } \\
\text { dipahami }\end{array}$ & $\begin{array}{l}\text { Iya, Jawa, } \\
\text { Sunda, Batak, } \\
\text { Maluku, } \\
\text { Papua, Betawi }\end{array}$ & $\begin{array}{l}\text { Peserta didik } \\
\text { SDN } \\
\text { Jatibening } \\
\text { Baru IV }\end{array}$ \\
\hline Sulit & Berdiskusi & Biasa Saja & Tidak & $\begin{array}{l}\text { Peserta didik } \\
\text { MI Miftahul } \\
\text { Amal }\end{array}$ \\
\hline Paham & Berdiskusi & $\begin{array}{l}\text { Mudah } \\
\text { dipahami }\end{array}$ & Iya, Jawa & $\begin{array}{l}\text { Peserta didik } \\
\text { MI Miftahul } \\
\text { Amal }\end{array}$ \\
\hline Seru & Berdiskusi & Biasa saja & $\begin{array}{l}\text { Iya, Budaya } \\
\text { Sunda }\end{array}$ & $\begin{array}{l}\text { Peserta didik } \\
\text { SDIT Ar- } \\
\text { Raudhah }\end{array}$ \\
\hline Seru & Berdiskusi & $\begin{array}{l}\text { Sulit } \\
\text { dipahami }\end{array}$ & Tidak & $\begin{array}{l}\text { Peserta didik } \\
\text { SDIT Ar- } \\
\text { Raudhah }\end{array}$ \\
\hline
\end{tabular}

Dari Tabel 4 dapat disimpulkan bahwa siswa SDN Jatibening Baru IV, MI Miftahul Amal, dan SDIT Ar-Raudhah umumnya memiliki pendapat yang beragam ketika menanggapi pelajaran matematika. Siswa di ketiga sekolah tersebut serupa dalam menjawab pertanyaan cara mengajar pendidik yaitu dengan berdiskusi. Namun terdapat kendala, dimana kurang menariknya materi yang terdapat pada bahan ajar dan juga materi yang sulit dipahami oleh siswa, sehingga pendidik terkadang menulis pembelajaran menggunakan media lain. Oleh sebab itu, siswa memperlukan desain pembelajaran yang menarik dan mudah dipahami.

\section{Design (Desain)}

Pada tahap ini, kegiatan yang dilakukan yaitu merumuskan tujuan pembelajaran pada desain pembelajaran berbasis etnomatematika kelas V SD. Tujuan pembelajaran tersebut yaitu a) Mengembangkan keterampilan berhitung. 


\section{Rismawati, Huri Suhendri, Ihwan Zulkarnain}

b) Membentuk sikap kritis, logis, kreatif dan inovatif. c) Membentuk keterampilan dalam mencari solusi. d) Membina pengembangan sikap rasa ingin tahu dan cara berpikir objektif dan mandiri. e) Menambah wawasan keberagaman budaya Indonesia.

Strategi pembelajaran yang digunakan yaitu strategi pembelajaran strategi pemecahan masalah. Pada strategi penemuan ini, peserta didik diajarkan untuk menemukan permasalahan dalam soal yang dikerjakan sendiri dan bertujuan supaya peserta didik dapat mengembangkan keterampilan berpikir analistis maupun keterampilan berimajinasi.

Pada strategi pemecahan masalah, peserta didik diajarkan untuk berpikir kritis dalam menyelesaikan soal yang berbasis masalah-masalah dalam bentuk nyata. Hal ini dilakukan supaya peserta didik dapat menyikapi dan terbiasa dalam menyelesaikan masalah baik di lingkungan sekolah maupun di luar lingkungan sekolah.

Selanjutnya, peneliti mengembangkan instrumen yang digunakan untuk evaluasi produk. Instrumen yang digunakan yaitu lembar penilaian ahli pakar dan lembar aktivitas peserta didik melalui beberapa latihan soal yang terdapat pada modul yang dikembangkan. Kisi-kisi instrumen yang dikembangkan mengacu pada kajian teori yang ada serta sesuai dengan kebutuhan data yang akan diperoleh peneliti.

\section{Development (Pengembangan)}

Pada tahap ini, peta kompetensi modul matematika berbasis budaya dan garis besar isi modul untuk tampilan-tampilan visual mulai dirancang. Setelah merancang peta kompetensi dan garis besar isi media, peneliti merancang tampilan media dan merancang tampilan desain media dengan mempersiapkan materi dan data gambar pada desain pembelajaran yang merupakan buatan pribadi peneliti secara manual menggunakan Adobe Photoshop, hal ini memudahkan peneliti dalam membuat design seperti cover dan background yang terdapat pada modul., serta memudahkan dalam memindahkan desain ke halaman Wps Office yang dibuat. Setelah design sudah berada di halaman Wps Office, peneliti memasukkan materi berupa teks dan gambar ke dalam masing-masing frame pada Wps Office. 
Pengembangan Desain Pembelajaran Matematika Kelas V SD Berbasis Etnomatematika
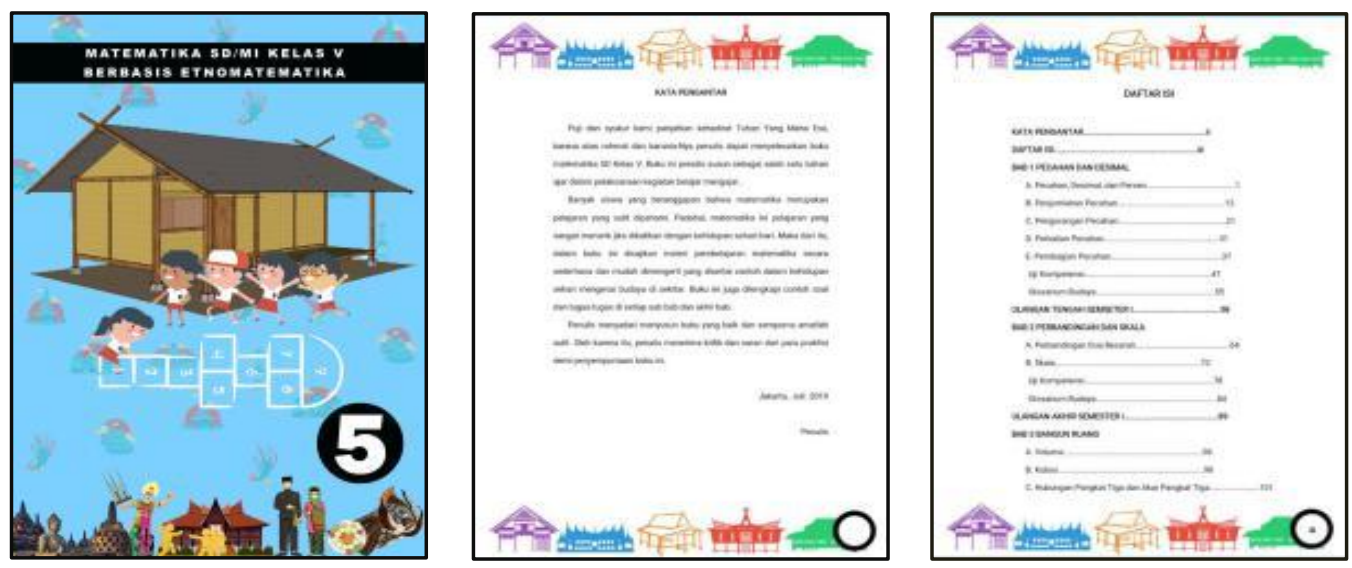

Gambar 2. Tampilan Cover, Kata Pengantar, dan Daftar Isi
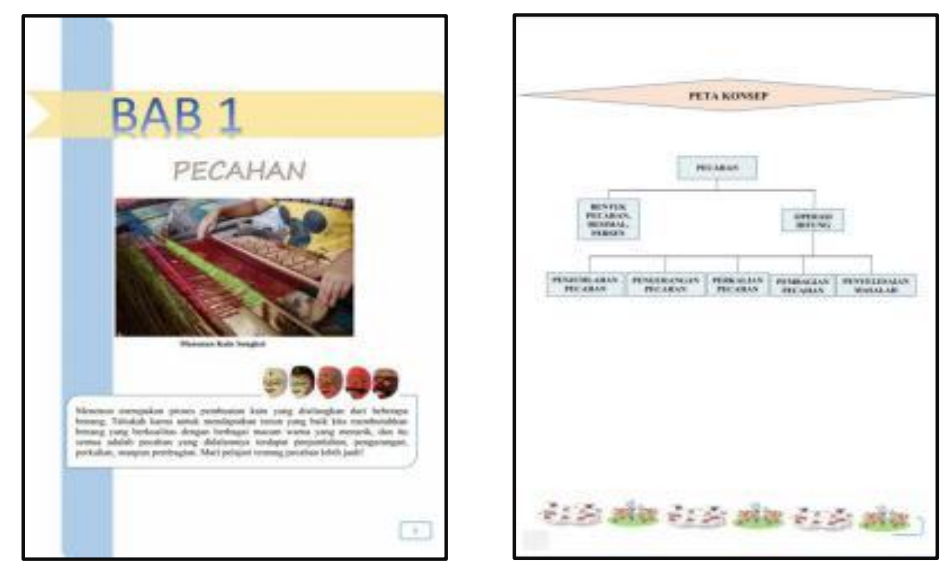

Gambar 3. Tampilan Judul Bab dan Peta Konsep
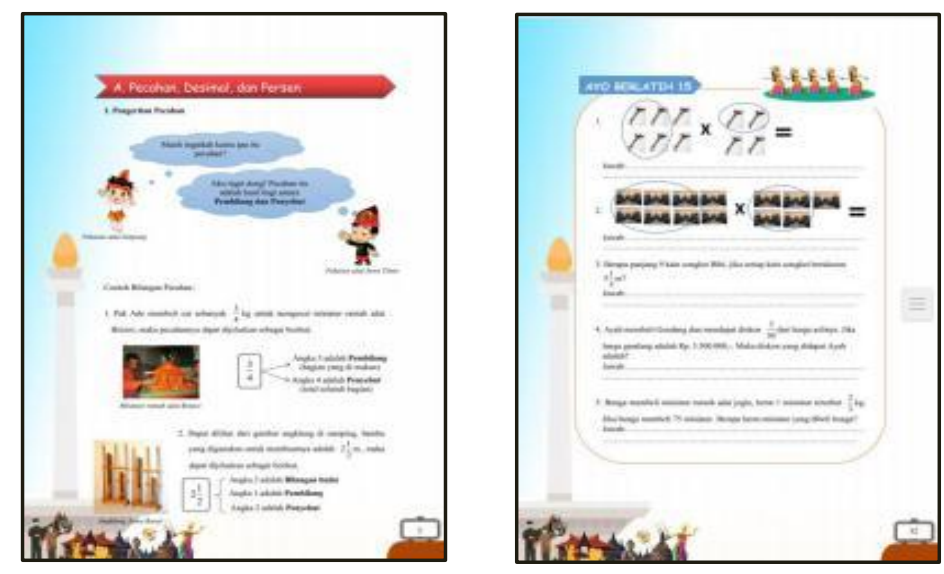

Gambar 4. Tampilan Sub Bab dan Materi Pembahasan dan Latihan Soal

\section{Implementation (Implementasi)}

Pada tahap implementasi ini peneliti melakukan uji coba desain 


\section{Rismawati, Huri Suhendri, Ihwan Zulkarnain}

pembelajaran dengan tujuan untuk mengetahui setiap detail kekurangan dan kelemahan dari desain yang telah selesai, untuk melihat efektif tidaknya desain pembelajaran tersebut bila digunakan oleh sasaran peserta didik yang dituju.

Uji coba desain pembelajaran matematika dilakukan pada kelompok kecil yang berjumlah masing-masing 5 peserta didik kelas V SD di SDN Jatibening Baru IV, MI Miftahul Amal, dan SDIT Ar-Raudhah. Tahap pertama adalah mendistribusikan desain pembelajaran berupa modul kepada peserta didik dengan memperkenalkan bagian-bagian yang terdapat pada modul. Tahap selanjutnya uji coba pembelajaran matematika kepada perwakilan 5 peserta didik di SDN Jatibening Baru IV, 5 peserta didik di MI Miftahul Amal, dan 5 peserta didik di SDIT Ar-Raudhah. Setelah itu, peneliti melakukan pembelajaran dengan menggunakan desain pembelajaran matematika. Setelah diakhir, peneliti menanyakan pendapat mengenai desain pembelajaran matematika kepada peserta didik.

Beberapa hasil penilaian berdasarkan uji coba pembelajaran yang dikerjakan oleh peserta didik diberikan pada Gambar 5.
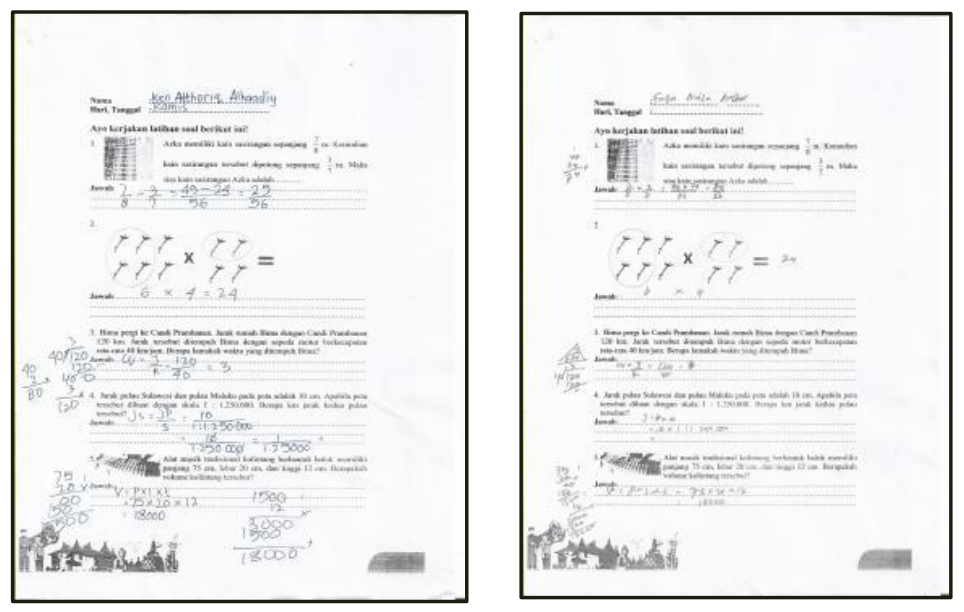

Gambar 5. Hasil Uji Coba Pembelajaran

\section{Evaluation (Evaluasi)}

Pada tahap ini, peneliti menganalisis data hasil pengisian lembar evaluasi yang diperoleh dari ahli pengembangan, ahli materi, dan ahli bahasa. Evaluasi bertujuan untuk melihat apakah sistem pembelajaran yang sedang dibangun berhasil sesuai dengan harapan awal atau tidak. Pakar yang dilibatkan terdiri dari 
1 orang pakar pengembangan, 1 orang pakar materi, dan 1 orang pakar bahasa.

a. Penilaian dari pakar pengembangan menggunakan penilaian dengan 15 butir pertanyaan dan skala penilaian 1 sampai 4. Hasil simpulan pakar pengembangan adalah total skor 55 dan rata-rata 3,67 (persentase 91,67\%), sehingga media pembelajaran kategori BAIK.

b. Penilaian dari pakar materi menggunakan penilaian dengan 11 butir pertanyaan dan skala penilaian 1 sampai 4. Hasil simpulan pakar pengembangan adalah total skor 41 dan rata-rata 3,73 (persentase 93,18\%), sehingga media pembelajaran kategori BAIK.

c. Penilaian dari pakar bahasa menggunakan penilaian dengan 12 butir pertanyaan dan skala penilaian 1 sampai 4. Hasil simpulan pakar pengembangan adalah total skor 38 dan rata-rata 3,17 (persentase 79,17\%), sehingga media pembelajaran kategori BAIK.

Berdasarkan hasil penilaian dari para pakar tersebut, maka buku pembelajaran matematika kelas V Sekolah Dasar ini memenuhi kualitas produk termasuk kriteria "sangat baik" dengan memperoleh hasil rata-rata 3,52 dan ratarata persentase $\mathbf{8 8 , 0 1 \%}$ sehingga dapat disimpulkan bahwa buku pembelajaran yang dikembangkan sudah baik.

Penelitian ini menggunakan metode penelitian dan pengembangan (Research and Development atau $R \& D$ ). $R \& D$ merupakan metode penelitian yang digunakan untuk dapat menghasilkan produk tertentu dan menguji keefektifan produk tersebut (Sugiyono, 2015). Model pengembangan yang digunakan dalam penelitian ini adalah model ADDIE (Analysis, Design, Development, Implementation, Evaluation). Gumanti (dalam Wulandari, dkk., 2017) menjelaskan bahwa model ADDIE mempunyai lima tahap pengembangan yaitu tahap analisis (analisis kurikulum, analisis karakteristik siswa, analisis situasi, dan analisis media), design atau perancangan (menyusun instrumen penilaian kualitas media pembelajaran, perancangan produk (flowchart), penyusunan materi, RPP, LKK, dan Soal Tes Hasil Belajar serta pengumpulan backsound, background, gambar, video dan tombol), development (pembuatan media dengan menggunakan software Adobe Flash CS3, validasi ahli media dan materi), implementation (uji coba perorangan, uji coba kelompok kecil, uji coba 


\section{Rismawati, Huri Suhendri, Ihwan Zulkarnain}

kelompok besar/pemakaian), evaluation (aktivitas siswa, aktivitas guru, respon siswa, tes hasil belajar).

Dalam penelitian ini, produk yang dikembangkan berupa bahan ajar untuk pembelajaran matematika bagi peserta didik kelas V SD/MI berbasis etnomatematika. Bahan ajar tersebut dikembangkan dalam rangka mengembangkan kerjasama peserta didik. D'Ambrosio (dalam Dahlan \& Permatasari, 2018) mengemukakan bahwa "penggunaan pembelajaran seharusnya dapat digunakan sebagai alat penyokong solidaritas dan kerjasama antar siswa”.

Bahan ajar pembelajaran matematika yang dikembangkan harus mampu meningkatkan kualitas pembelajaran dan efektif bagi peserta didik. Selain itu, diharapkan mampu memfasilitasi pencapaian kompetensi-kompetensi peserta didik. Menurut Rahmawati dan Suhendri (2016), “penelitian pengembangan ini bertujuan untuk mengembangkan desain pembelajaran yang tepat dan sesuai bagi peserta didik Sekolah Dasar kelas 6. Penelitian pengembangan ini menggunakan Model Pengembangan Intruksional (MPI) dan menunjukkan hasil yaitu tersusunnya bahan ajar yang efektif bagi peserta didik Sekolah Dasar kelas 6 pada mata pelajaran matematika".

Berdasarkan hasil penelitian bahan ajar pembelajaran yang dikembangkan peneliti tersebut melakukan evaluasi formatif yang bertujuan untuk menentukan apa yang harus ditingkatkan, agar produk lebih sistematis, efektif, dan efisien. Evaluasi formatif yang dilakukan yaitu review oleh para ahli di luar tim pendesain intruksional. Hal ini dimaksudkan untuk memperoleh pendapat dari pihak lain, sesama ahli tentang bagaimana aspek ketepatan konten menurut ahli bidang studi, memadai atau tidaknya strategi intruksional dari pendesain bidang studi, dan desain fisik dari ahli media.

Dari beberapa masukan validator dan dilakukan beberapa kali revisi, bahan instruksional diharapkan mampu memfasilitasi pencapaian kompetensikompetensi peserta didik kelas V SD dalam pemecahan masalah matematis. Hasil dari pengembangan desain instruksional ini adalah produk berupa bahan ajar yang memuat materi SD kelas V. Bahan ajar ini dilengkapi dengan Tujuan Instruksional Umum (TIU), Tujuan Instruksional Khusus (TIK), indikator pencapaian kompetensi, peta konsep, latihan-latihan yang mengaplikasikan 


\section{Pengembangan Desain Pembelajaran Matematika Kelas V SD Berbasis Etnomatematika}

metode pembelajaran dari strategi pembelajaran kooperatif, serta dilengkapi dengan uji kemampuan dan latihan akhir tahun untuk mengukur sejauh mana pencapaian kompetensi peserta didik. Oleh karena itu, peneliti ingin mengembangkan desain pembelajaran matematika berbasis etnomatematika untuk kelas V Sekolah Dasar.

Desain pembelajaran yang peneliti kembangkan agar peserta didik dapat lebih memahami pelajaran matematika dan memahami budaya di sekitarnya. Peneliti memilih mengembangkan desain pembelajaran matematika yang menampilkan keberagaman budaya di sekitar dan menampilkan latihan soal cerita dan soal latihan HOTS yang dapat meningkatkan kemampuan kognitif, afektif, maupun psikomotorik peserta didik.

Pada tahap awal peneliti menganalisis kebutuhan peserta didik, menganalisis karakteristik peserta didik, kemampuan awal peserta didik dalam mengerjakan soal matematika sederhana, dan ditentukan materi yang di sesuaikan dengan kurikulum yang berlaku yaitu kurikulum 2013. Pada tahap ini dilakukan studi pendahuluan yakni berupa wawancara dan memberikan kuesioner dengan pendidik dan peserta didik.

Tahap selanjutnya adalah tahap desain, pada tahap ini peneliti membuat peta konsep, garis besar isi media, storyboard, serta merancang materi yang digunakan dalam membuat desain pembelajaran yang dikembangkan. Pembuatan desain pembelajaran dilakukan dengan membuat tampilan cover maupun background yang akan di gunakan pada modul. Selanjutnya adalah tahap pengembangan desain pembelajaran.

Tahap pengembangan dilakukan dengan membuat materi, latihan soal, rangkuman, kuis, uji kompetensi, maupun glosarium budaya dari setiap bab yang akan ditampilkan pada desain pembelajaran. Kemudian, dibuatlah desain pembelajaran sesuai dengan storyboard yang telah peneliti buat. Tahap selanjutnya, desain pembelajaran divalidasi oleh dosen ahli dan salah satu pendidik di sekolah. Saran dan komentar yang diperoleh dari hasil validasi digunakan sebagai acuan dalam memperbaiki desain pembelajaran. Adapun saran dan komeentar yang diberikan adalah mengubah cover pada modul, memperhatikan penggunaan tanda baca dan tanda pisah pada kalimat, dan 


\section{Rismawati, Huri Suhendri, Ihwan Zulkarnain}

sebaiknya latihan soal lebih bervariasi sesuai dengan tingkat kesukaran.

\section{SIMPULAN}

Berdasarkan hasil penelitian dan pembahasan, maka dapat disimpulkan bahwa pengembangan desain pembelajaran matematika kelas V SD berbasis etnomatematika memenuhi langkah-langkah model pengembangan ADDIE. Desain pembelajaran yang dikembangkan berupa bahan ajar matematika bagi peserta didik kelas V SD berbasis etnomatematika sesuai dengan kebutuhan guru dan peserta didik berdasarkan analisi kebutuhan. Selain itu juga berdasarkan penilaian dan masukan pakar sehingga bahan ajar matematika bagi peserta didik kelas V SD berbasis etnomatematika sudah sesuai tahapan penelitian dan pengembangan ADDIE.

\section{DAFTAR PUSTAKA}

Afandi, M., dkk. (2013). Model dan Metode Pembelajaran di Sekolah. Semarang: Unissula Press.

Dahlan, J. A., \& Permatasari, R. (2018). Development of Instructional Materials Based on Ethnomathematic in Mathematics Learning in Junior High School. JNPM (Jurnal Nasional Pendidikan Matematika), 2(1), 133-150.

Fahmi, S., \& Marsigit. (2014). Pengembangan Multimedia Macromedia Flash dengan Pendekatan Kontekstual dan Keektifannya terhadap Sikap Peserta didik pada Matematika. Pythagoras: Jurnal Pendidikan Matematika, 9(1), 90-98.

Nasaruddin. (2013). Karakteristik dan Ruang Lingkup Pembelajaran Matematika di Sekolah. Al-Khawarizmi: Jurnal Pendidikan Matematika dan Ilmu Pengetahuan Alam, 1(2), 63-76.

Nusantara, T., \& Rahardjo, S. (2017). Ethnomathematics In Arfak (West PapuaIndonesia): Numeracy of Arfak. International Journal of Scientific \& Technology Research, 6(9), 325-327.

Novianingsih, H. (2016). Pendekatan Pembelajaran Aktif, Kreatif, dan Menyenangkan dalam Pembelajaran Matematika Sekolah Dasar. Jurnal Pendidikan Guru Sekolah Dasar, 1(1), 1-11.

Rahmawati, E., \& Suhendri, H. (2016). Pengembangan Desain Pembelajaran Matematika Peserta Didik Sekolah Dasar Kelas 6. Formatif: Jurnal Ilmiah Pendidikan MIPA, 6(3), 184-196.

Sugiyono. (2015). Metode Penelitian Kuantitatif, Kualitatif dan R\&D. Bandung: Alfabeta

Suhendri, H. (2013). Pengaruh Metode Pembelajaran Problem Solving terhadap Hasil Belajar Matematika Ditinjau dari Kemandirian Belajar. Formatif: Jurnal Ilmiah Pendidikan MIPA, 3(2), 105-114.

Suhendri, H., \& Ningsih, R. (2018). Peranan Ketahanmalangan dan Kreativitas 
dalam Pembelajaran Matematika. JPPM (Jurnal Penelitian dan Pembelajaran Matematika, 11(1), 31-40.

Sumianto. (2018). Penerapan Pendekatan Matematika Realistik (MPR) untuk Meningkatkan Hasil Belajar Matematika Peserta didik Kelas V Al-Azim SDIT Raudhatur Rahmah Pekanbaru. Jurnal Basicedu, Journal of Elementary Education, 2(1), 49-56.

Trisiana, A., \& Wartoyo. (2016). Desain Pengembangan Model Pembelajaran Pendidikan Kewarganegaraan melalui ADDIE Model untuk Meningkatkan Karakter Mahasiswa di Universitas Slamet Riyadi Surakarta. PKn Progresif, 11(1), 312-330.

Vasquez, E. L. (2017). Ethnomathematics as An Epistemological Booster for Investigating Culture and Pedagogical Experience with The Young Offender or Prison School Communities. Journal of Educationand Human Development, 6(2), 117-127

Wijanarko, A. (2017). Pengembangan Media Apatar Satu pada Materi Satuan Waktu Mata Pelajaran Matematika Kelas V. Universitas PGRI Yogyakarta

Wulandari, S., Ainy, C., \& Suprapti, E. (2017). Pengembangan Media Pembelajaran Matematika Berbasis Games Interaktif Menggunakan Aplikasi Adobe Flash CS3 pada Materi Pokok Trigonometri Kelas X SMKN 10 Surabaya. MUST: Journal of Mathematics Education, Science \& Technology, 2(2), 165-177.

Zuriah, N., Sunaryo, H., \& Yusuf, N. (2016). IBM Guru dalam Pengembangan Bahan Ajar Kreatif Inovatif Berbasis Potensi Lokal. Jurnal DEDIKASI, 13(1), 39-49. 